\title{
O SUBGRUPO ITARARÉ, PERMOCARBONÍFERO DA REGIÃO DO MÉDIO TIETÊ, ESTADO DE SÃO PAULO: ESTUDOS EM SUBSUPERFÍCIE
}

\author{
Setembrino PETRI \\ Percy Corrêa VIEIRA \\ Geraldo Hideo ODA \\ Pedro Fernandes BOTELHO
}

\begin{abstract}
RESUMO
A presente contribuição enfoca poços perfurados pelo Instituto Geológico da Secretaria do Meio Ambiente do Estado de São Paulo (IG-SMA), na região do Médio Rio Tietê, Estado de São Paulo. Os referidos poços atravessaram sedimentos do Subgrupo Itararé, Permocarbonífero da Bacia do Paraná. Alguns poços cortaram intrusivas básicas de idade cretácica. Para efeito de comparações das colunas sedimentares, recuperadas através de testemunhagem completa, os poços foram grupados de acordo com as respectivas situações geográficas em relação à borda atual da Bacia Sedimentar do Paraná: I - poços situados até a distância de cerca de $30 \mathrm{~km}$ da borda da bacia; II - poços situados na região Capivari-Rafard; III - poços situados no vale do rio Tietê, ao redor da cidade de Tietê e dos distritos de Sete Fogões e Jumirim; IV - poço localizado em Mombuca, situado a cerca de $10 \mathrm{~km}$ a noroeste de Capivari. Pormenores das sucessões litológicas e da produtividade dos poços permitem ressaltar diferenças entre estas regiões.
\end{abstract}

\section{ABSTRACT}

The aim of the present contribution is to compare the lithologies of wells drilled by the Instituto Geológico, Secretaria do Meio Ambiente of the State of São Paulo (IG-SMA), for ground water. The wells were located in the middle Tietê River Valley, State of São Paulo. Most of these wells are $300 \mathrm{~m}$ deep and thoroughly cored. Their sediments are referred to the Paraná Basin Permo-Carboniferous Itararé Subgroup. Cretaceous intrusive rocks are also present. The wells were grouped accordingly to geographical location within the middle Tietê river valley. Four groups of wells were considered: I - wells located as far as $30 \mathrm{~km}$ from the present Paraná sedimentary basin border; II - wells located in the Capivari/Rafard region; III wells located near the Tietê river margins, around the town of Tietê as well as around the Sete Fogões and Jumirim villages; IV - one well located near Mombuca, about $10 \mathrm{~km}$ northwest of Capivari.

\section{INTRODUÇÃO}

A necessidade de abastecimento de água para as cidades da região do Médio Tietê, Estado de São Paulo, tem propiciado a perfuração de poços tubulares pelo Instituto Geológico da Secretaria do Meio Ambiente, do Estado de São Paulo (IG-SMA) e também por firmas particulares.

As atividades do IG-SMA na região, são anteriores a 1985. Contudo, a partir deste ano, foram realizadas descrições pormenorizadas das litologias atravessadas pelos poços, graças a testemunhagem completa, o que, infelizmente não ocorreu com as firmas particulares (FIGURA 1).

Na TABELA 1, estão especificados os poços perfurados pelo IG-SMA de 1985 a 1995, com: localização, cota de boca, profundidade, espessura de regolito, espessura de diabásio e porcentagem das litologias atravessadas, em termos de psefitos, psamitos, pelitos e a capacidade específica $\left(\mathrm{m}^{3} / \mathrm{h} / \mathrm{m}\right)$ de cada poço. Consta, também, relacionado um poço construído por companhia particular, no município de Tietê. 
Embora os estudos tenham se concentrado nos poços perfurados pelo IG-SMA desde 1985, alguns dados de poços perfurados antes de 1985, foram considerados com a finalidade de se complementarem os estudos.

São consideradas neste trabalho, as formações Itu (basal) e Capivari propostas por STEVAUX et al. (1987), redefinindo unidades de BARBOSA \& ALMEIDA (1949). A Formação Itu é basicamente psamítica, com tilitos s.s.; outras litologias são subordinadas; está em contato com o embasamento pré-cambriano. A Formação Capivari é marinha, recobrindo a Formação Itu através de uma superfície de afogamento (PETRI \& PIRES, 1992); basicamente é constituída por psamitos e pelitos, com psefitos sob a forma de fluxos de detritos.

O objetivo da presente contribuição é a comparação das diversas áreas que constituem o médio vale do rio Tietê, com base nas descrições litológicas e dados da produtividade dos poços.

\section{METODOLOGIA}

Os sedimentos atravessados pelas sondas foram analisados de acordo com suas litologias. Os pacotes sedimentares foram classificados em três categorias: psefitos, psamitos e pelitos, calculando-se as porcentagens de cada uma destas categorias em cada poço. Na categoria de psefitos, foram grupados conglomerados, brechas e diamictitos; na de psamitos, arenitos, desde conglomeráticos até muito finos (com ou sem clastos) e arcósios; na de pelitos, argilitos, siltitos, ritmitos (argilitos/siltitos), lamitos (com ou sem clastos), calcários impuros e folhelhos.

Esta metodologia, apesar da distribuição irregular dos poços, revelou tendências que permitiram a distinção de quatro grupos (regiões) de poços, abaixo discriminados (FIGURA 1).

Como boa parte das colunas litológicas dos poços perfurados na região Capivari-Rafard já foi estudada e figurada em trabalhos anteriores (PETRI, 1992; PETRI \& PIRES, 1992; PETRI et al., 1996), na presente contribuição, estas colunas não foram apresentadas.

Alguns poços da região I, situados até 30 km da borda da bacia do Paraná e da região próxima às margens do rio Tietê, foram aqui descritos e figurados. $\mathrm{O}$ único poço da região IV, Mombuca, já foi descrito e figurado em trabalho anterior (PETRI, 1992) razão de sua não reapresentação neste trabalho.

Para uma análise geral das produtividades dos poços relacionados na TABELA 1 , os dados foram correlacionados com as respectivas espessuras de psamitos dos poços.

Para o cálculo da produtividade foi utilizado o parâmetro Capacidade Específica $\left(\mathrm{m}^{3} / \mathrm{h} / \mathrm{m}\right)$, que corresponde à relação entre a vazão $\left(\mathrm{m}^{3} / \mathrm{h}\right)$ e respectivo rebaixamento do nível d'água do poço em metros.

\section{RESULTADOS}

\subsection{Comparações dos poços do Médio Tietê}

Os poços podem ser distribuídos, sob o ponto de vista combinado das respectivas posições geográficas e estratigráficas, em quatro grupos especificados abaixo, e mais um poço perfurado no município de Mombuca (FIGURA 1).

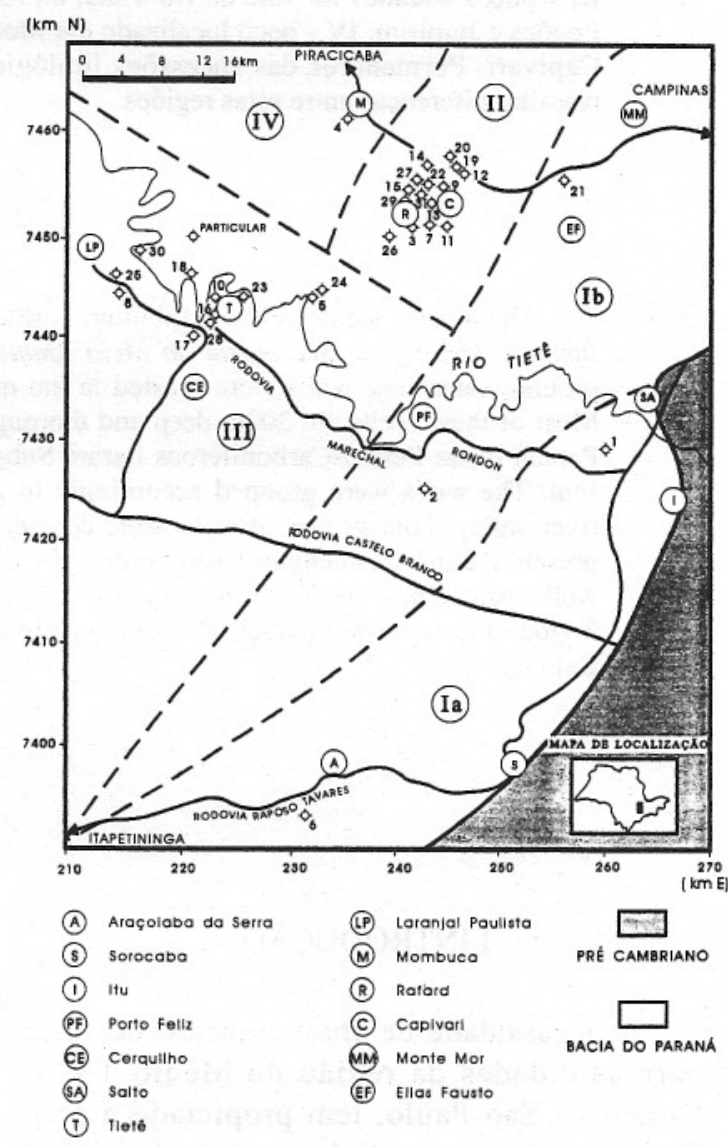

FIGURA 1 - Localização geral dos poços. Os números romanos Ia, Ib, II, III e IV se referem aos grupos e subgrupos de poços, divididos de acordo com as respectivas posiçõ̃es geográficas.

I - Poços situados a cerca de $30 \mathrm{~km}$ da borda atual da bacia sedimentar do Paraná: $\mathrm{n}^{\circ} 1$, 2,6 e 21 . 


\begin{tabular}{|c|c|c|c|c|c|c|c|c|c|c|c|c|c|}
\hline \multirow{2}{*}{$\begin{array}{l}\mathrm{N}^{\circ} \\
01\end{array}$} & LOCALIDADE & SIGLA & FOLHA & \multicolumn{2}{|c|}{$\begin{array}{l}\text { COORDENADAS UTM } \\
\text { KM-E KM-N }\end{array}$} & \multirow{2}{*}{$\begin{array}{c}\begin{array}{c}\text { COIA } \\
\text { DA } \\
\text { BOCA }\end{array} \\
515,0\end{array}$} & \multirow{2}{*}{$\begin{array}{c}\begin{array}{c}\text { PROFUN } \\
\text { DIDADE } \\
\text { (m) }\end{array} \\
261.5\end{array}$} & \multirow{2}{*}{$\begin{array}{r}\text { REGOU- } \\
\text { TO }(\mathrm{m}) \\
14,0\end{array}$} & \multirow{2}{*}{$\begin{array}{l}\begin{array}{l}\text { PSE- } \\
\text { FITOS }\end{array} \\
12,0\end{array}$} & $\begin{array}{l}\text { UTOLOO } \\
\text { PSA- } \\
\text { MITOS }\end{array}$ & $\begin{array}{l}\text { SAS (m) } \\
\text { PEU. } \\
\text { TOS }\end{array}$ & $\begin{array}{l}\text { DIA- } \\
\text { BÁSIOS }\end{array}$ & $\begin{array}{c}\text { CAESP } \\
\left(\mathrm{m}^{3} / \mathrm{h} / \mathrm{m}\right)\end{array}$ \\
\hline & $\mathrm{mU}$ & $\pi-1 G / 85$ & SALTO & 259.55 & 7428.70 & & & & & 151.5 & 84,0 & 0,0 & 0,05 \\
\hline $\mathrm{O2}$ & PORTO FELIZ & PF-1G/85 & BOTIUVA & 242,70 & 7425,25 & 550,0 & 80,0 & 8,0 & 3,0 & 25,0 & 37,0 & 0,0 & 0,04 \\
\hline 23 & \begin{tabular}{|l} 
RAFARD \\
\end{tabular} & $R-1 G / 85$ & PORTOFELIZ & 241,45 & 7451,65 & 506,0 & 301,0 & 9.6 & 31,0 & 167.4 & 93.0 & 0,0 & 0.89 \\
\hline 04 & MOMBUCA & M-IG/85 & CAPNARI & 234,95 & 7462.10 & 548,0 & 200,0 & 4.0 & 91,5 & 41,2 & 83,3 & 0,0 & 0.34 \\
\hline 05 & SEIE FOGÓES & SF-1G/85 & PORTOFELIZ & 232,70 & 7443,85 & 521,0 & 130,0 & 8.0 & 0,0 & 109,7 & 8,3 & 0,0 & 1,35 \\
\hline 06 & ARAC.. SERRA & A-1G/86 & SALI. PIRAP. & 231.60 & 7392,80 & 620,0 & 212,7 & 0,0 & 25,6 & 31,3 & 155.8 & 0.0 & 0,01 \\
\hline 07 & CAPNARI & C-1G/86 & PORIO FELIZ & 243,40 & 7452,00 & 510,0 & 301,1 & 11,0 & 15,3 & 180,4 & 94,4 & 0,0 & 0,76 \\
\hline 08 & JUMIRIM & $-1 / G / 86$ & LARANW. PTA. & 213,70 & 7443,95 & 560,0 & 193,0 & 9.3 & 35,2 & 61,4 & 87.1 & 0,0 & 0.20 \\
\hline 09 & CAPNARI & $C-1 G / 87$ & AMERICANA & 244,10 & 7455,00 & 500,0 & 310.0 & 13,8 & 13.4 & 199.4 & 83,4 & 0,0 & 0.25 \\
\hline 10 & MEIE & $T-1 G / 87$ & PORTO FELIZ & 223,70 & 7443,55 & 534,0 & 300,7 & 7.8 & 102,1 & 128,8 & 57.7 & 4,3 & 1.04 \\
\hline 11 & CAPNARI & C-1G/89 & SALIO & 244,50 & 7451,50 & 540,0 & 275,5 & 0,0 & 22,1 & 170,2 & 83.2 & 0.0 & 0.10 \\
\hline 12 & CAPNARI & C2-1G/89 & AMERICANA & 245,80 & 7456,55 & 500,0 & 268,0 & 4,8 & 0,3 & 226,0 & 36.9 & 0.0 & 0,40 \\
\hline 13 & CAPNAARI & C-1G/90 & PORTO FELIZ & 243,30 & 7453,60 & 515.0 & 101,4 & 11,0 & 3,0 & 33,1 & 54,3 & 0,0 & \\
\hline 14 & CAPNARI & $C-\mid G / 91$ & CAPNARI & 242,75 & 7456,55 & 530.0 & 300,3 & 8.0 & 5,2 & 268,3 & 18,8 & 0.0 & 0,97 \\
\hline 15 & CAPIVARI & $C 2-1 G / 91$ & CAPNARI & 241,00 & 7454,55 & 490,0 & 252,7 & 4,0 & 0,3 & 218.0 & 30.4 & 0.0 & 2.02 \\
\hline 16 & MEIÉE & $T-1 G / 90$ & PORTO FELLZ & 221,90 & 7441,80 & 505,0 & 300,0 & 6.0 & 3.6 & 212,3 & 77.1 & 0,0 & 1,45 \\
\hline 17 & MEIE्E & $T-\mid G / 91$ & PORTO FELIZ & 220.75 & 7440.70 & 490,0 & 303,0 & 0,0 & 4,5 & 45,8 & 33.2 & 53,5 & 0,34 \\
\hline 18 & MEIE & II-1G/91 & PORTO FELIZ & 220,30 & 7446,30 & 483,0 & 299,5 & 22.0 & 22,3 & 189.7 & 61.1 & 4.4 & 0.99 \\
\hline 19 & CAPNARI & C- $1 G / 92$ & AMERICANA & 245,50 & 7456,60 & 503,0 & 300,0 & 9,0 & 0,5 & 248.1 & 42,4 & 0.0 & 1.09 \\
\hline 20 & CAPNARI & $\mathrm{C} 1-1 \mathrm{G} / 92$ & AMERICANA & 244,50 & 7456.70 & 550,0 & 274,3 & 0,0 & 6,2 & 196,0 & 66,1 & 0.0 & 0,45 \\
\hline 21 & CAPNARI & $\mathrm{C} 2-\mathrm{KG} / 92$ & AMERICANA & 255,45 & 7455,80 & 525,0 & 300,5 & 3,0 & 5,5 & 140,3 & 151.7 & 0,0 & 0,45 \\
\hline 22 & CAPNARI & C-1G/93 & CAPNAARI & 242,25 & 7455,10 & 505,0 & 300,0 & 17,0 & 21,8 & 243,0 & 18.2 & 0.0 & 0.06 \\
\hline 23 & MEIE & T-1G/93 & PORIO FEIIZ & 224.00 & 7444.20 & 480,0 & 300,0 & 0.3 & 57,0 & 203.1 & 36.1 & 3.5 & 1.29 \\
\hline 24 & SEIE FOGÓES & SF-1G/93 & PORIO FELIZ & 233,00 & 7444.25 & 525,0 & 160,0 & 8,0 & 2,1 & 142,8 & 7.1 & 0.0 & 0.25 \\
\hline 25 & JUMIRIM & J-IG/93 & LARANU. PTA. & 214,15 & 7444,95 & 503,0 & 300,8 & 9,0 & 4,7 & 147.5 & 137.9 & 0.7 & 0,40 \\
\hline 26 & RAFARD & $R-1 G / 94$ & PORIO FELIZ & 239,80 & 7449,05 & 540,0 & 300,0 & 6,0 & 6,2 & 150,3 & 129.1 & 0.0 & 0.23 \\
\hline 27 & CAPPARI & C-1G/94 & CAPIVARI & 241.79 & 7454,75 & 520,0 & 300,0 & 4,7 & 0,0 & 253,3 & 42,0 & 0,0 & 0,76 \\
\hline 28 & METÉ & $T-K / 94$ & PORTO FELIZ & 223,50 & 7441,30 & 540,0 & 258,0 & 18,0 & 8,8 & 139,1 & 39,4 & 35,4 & 0,76 \\
\hline 29 & RAFARD & R-1G/95 & PORIO FELIZ & 240,80 & 7452,70 & 540,0 & 283.0 & 15,9 & 0,5 & 152,2 & 114,5 & 0.0 & 0.72 \\
\hline 30 & TEÊE & $\mathrm{T}-\mathrm{KG} / 95$ & PORTO FELIZ & 217.40 & 7447,70 & 545,0 & 194,0 & 24,3 & 37,4 & 73,4 & 51.2 & 4.1 & 0,20 \\
\hline 31 & CAPIVARI & C-1G/95 & PORIO FELIZ & 242,70 & 7454.20 & 505,0 & 300,0 & 4.9 & 14,1 & 239,7 & 40,6 & 0,0 & 0,40 \\
\hline
\end{tabular}

POCCO PROFUNDO PERFURADO POR EMPRESA PARIICULAR

\begin{tabular}{|l|l|l|l|l|l|l|l|l|l|l|l|l|l|}
\hline G.S. & MEIE & TP-89 & PORTOFELI & 220,60 & 7450,00 & 590 & 154 & 12,5 & 13,8 & 88,4 & 25,8 & 13,5 & \\
\hline
\end{tabular}

A SÁO JOSÉ.

PSEFITOS: CONGLOMERADOS, BRECHAS E DIAMICITOS.

PSAMITOS: ARENITOS CONGLOMERÁIICOS A MUITO FINOS (COM OU SEM CLASTOS), ARCÓSEOS.

PELITOS: ARGLITOS, SILITIOS, RIMMITOS (ARGILITO/SILITO), LAMTOOS (COM OU SEM CLASTOS), CALCÁRIOS IMPUROS E FOLHELHOS.

CAESP: CAPACIDADE ESPECIFICA. 
Foram considerados dois subgrupos do grupo I: Ia - poços cuja proximidade em relação à borda da bacia permitiu que o embasamento cristalino fosse atingido pela perfuração; Ib poços relativamente afastados da borda, de modo que o embasamento não foi atingido pela perfuração. Supõe-se, contudo, que o embasamento estivesse próximo do fundo destes poços.

II - Poços da região Capivari-Rafard (FIGURA 2): $\mathrm{n}^{\circ} 3,7,9,11,12,13,14,15,19$, 20, 22, 26, 27, 29 e 31 .

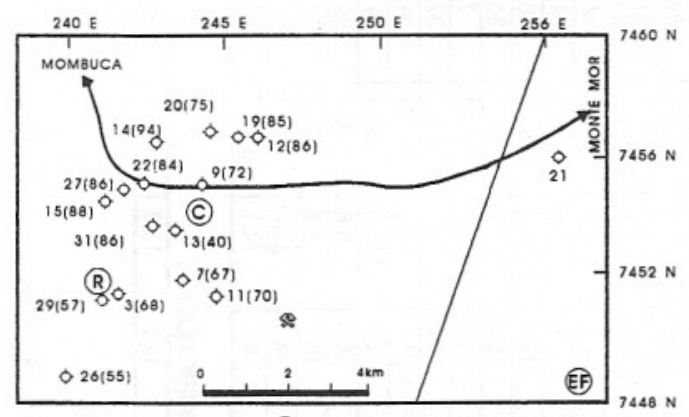

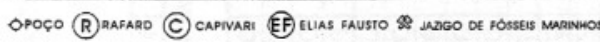

FIGURA 2 - Poços da região de Capivari Rafard. Os números da figura têm os seguintes significados: fora dos parênteses - número do poço; entre parênteses - porcentagem de psefitos mais psamitos, em relação às litologias totais dos poços, não se considerando os regolitos. Por exemplo, 11(70), significa o poço número 11 , onde $70 \%$ da coluna litológica é constituída por psefitos mais psamitos.

III - Poços situados próximos às margens do rio Tietê, ao redor da cidade de Tietê e dos distritos de Sete Fogões e Jumirim (FIGURA 3): $\mathrm{n}^{\circ} 5,8,10,16,18,23,24,25,28,30$ e o referido poço particular.

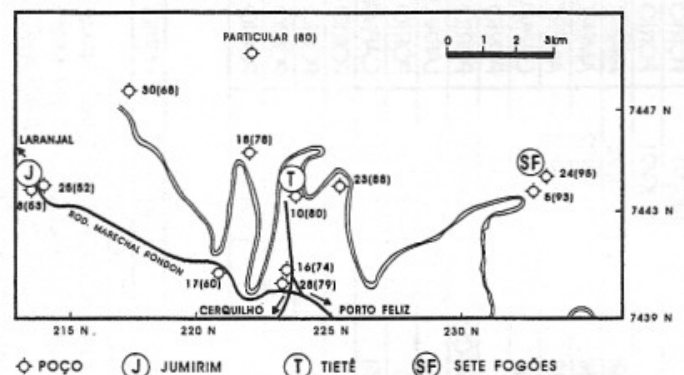

FIGURA 3 - Poços da Região de Tietê. O número entre parênteses corresponde a porcentagem de psefitos mais psamitos.

IV - Um poço situado no município de Mombuca, cerca de $10 \mathrm{~km}$ a noroeste de Capivari, $\mathrm{n}^{\circ} 4$.
3.2 - Poços situados até $30 \mathrm{~km}$ da borda atual da bacia

3.2.1 Subgrupo Ia - Os seguintes poços perfurados pelo IG-SMA, atingiram o embasamento: poço 6 (A-86), situado ao sul de Araçoiaba da Serra, região de Sorocaba, com o embasamento alcançado a $212 \mathrm{~m}$ da boca do poço: poço 1 (It-85), situado na área de Itu, com o embasamento a $261,5 \mathrm{~m}$ da boca do poço.

Antes de 1985, o IG-SMA perfurou diversos poços na região de Itu. Na fábrica de bebidas Schincariol, situado a pouco mais de 2 $\mathrm{km}$ ao sul do poço 1, o IG-SMA perfurou quatro poços. O embasamento foi atingido a profundidades que variaram de 75 a $110 \mathrm{~m}$ da boca do poço. A sondagem do condomínio Vila Real de Itu, situado a pouco menos de $6 \mathrm{~km}$ a sudoeste do poço 1 , chegou a $262,5 \mathrm{~m}$, sem atingir o embasamento, o qual estaria a uma distância próxima do fundo do poço.

Em muitos poços da região de Itu, abaixo de um espesso pacote de ritmitos "tipo varvito de Itu", ocorrem seções predominantemente arenosas, com diamictitos e pelitos subordinados. Esses arenitos basais corresponderiam a depósitos não marinhos (ou mistos), transgressivos, considerados da Formação Itu (STEVAUX et al., 1987; PETRI, 1992).

Acima desta seção arenosa basal, ocorre o espesso ritmito supramencionado, o qual representaria fase de afogamento causada por subida brusca do nível do mar. Como o mar deve ter vindo de sudoeste, no poço de Araçoiaba (poço 6 - A-86), situado a sudoeste dos poços de Itu, a fase pré-mar Capivari está representada por pequena espessura de sedimentos, pouco mais de $20 \mathrm{~m}$, sucedida logo por seção predominante de pelitos com delgados níveis de diamictitos. Esta seção pelítica possui espessura de $155,8 \mathrm{~m}$ até a boca do poço (MASSOLI, 1991; SOUZA, 1996), continuando acima, através de afloramentos descontínuos, até os cortes da rodovia Sorocaba-Itapetininga, onde estes pelitos contêm fósseis marinhos. A espessura total, predominantemente pelítica, envolvendo a coluna do poço e os afloramentos, acima do poço, perfaz pouco mais de $166,2 \mathrm{~m}$. Os palinomorfos foram estudados por SOUZA (1996), que chegou a idade westphaliana para os sedimentos marinhos desta região.

As capacidades específicas destes poços são, respectivamente, 0,05 e 0,01 .

3.2.2 Subgrupo $1 \mathrm{~b}$ - Inclui-se neste subgrupo o poço da rodovia Capivari-Monte Mor (poço 21 - C2-92), situado a cerca de $30 \mathrm{~km}$ da 
borda atual da bacia do Paraná, na região de Campinas e o de Porto Feliz (poço 2 ou PF-85), situado a cerca de $24 \mathrm{~km}$ da borda da bacia do Paraná, a WSW de Itu.

Estes dois poços exibem seções pelíticas mais espessas que as psamíticas. Contudo, a seção predominantemente pelítica do poço 21 , cerca de $150 \mathrm{~m}$, está situada acima da seção predominantemente psamítica, enquanto no poço 2 ocorre o inverso.

De acordo com o modelo adotado, a seção psamítica inferior do poço 21 , pertenceria à Formação Itu sendo, neste aspecto, semelhante às seções dos poços da região de Itu.

A seção predominantemente pelítica do poço 2 ocorre na base. Este poço foi perfurado só até a profundidade de $80 \mathrm{~m}$. Como a seção pelítica representaria a fase de afogamento que marcaria o início da Formação Capivari, deduzse que a Formação Itu não teria sido atingida neste poço e que os psamitos deste poço estariam incluídos na Formação Capivari, tendo sido originados por fluxos de detritos que avançariam mar adentro. Outra hipótese a ser considerada seria de que estes psamitos, intercalados com pelitos, acima da parte basal de pelitos de $29 \mathrm{~m}$, seriam reflexos de interdigitações Itu/Capivari (FIGURA 4).

GAMA Jr. et al. (1991) interpretaram a base dos arenitos da "Gruta de Porto Feliz", situada junto à cidade de Porto Feliz, margem esquerda do rio Tietê, como de origem fluvial, o que se coadunaria com a hipótese de interdigitação Itu/Capivari. Contudo, grande parte dos

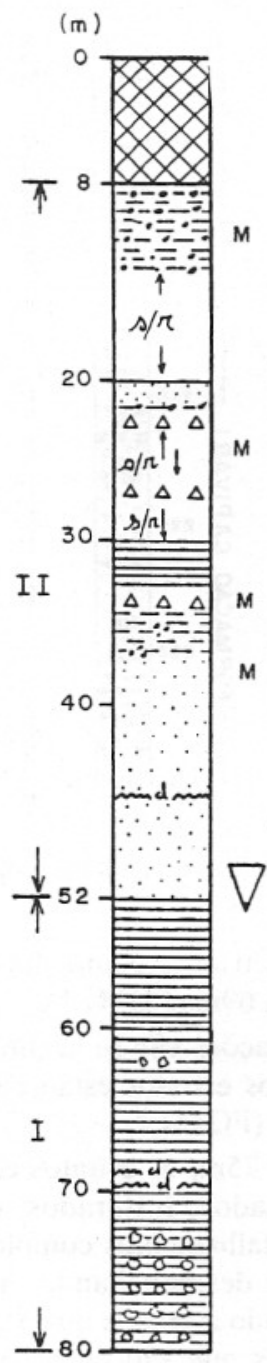

FIGURA 4 - Seção geológica do poço de Porto Feliz n 2 (PF-IG/85).

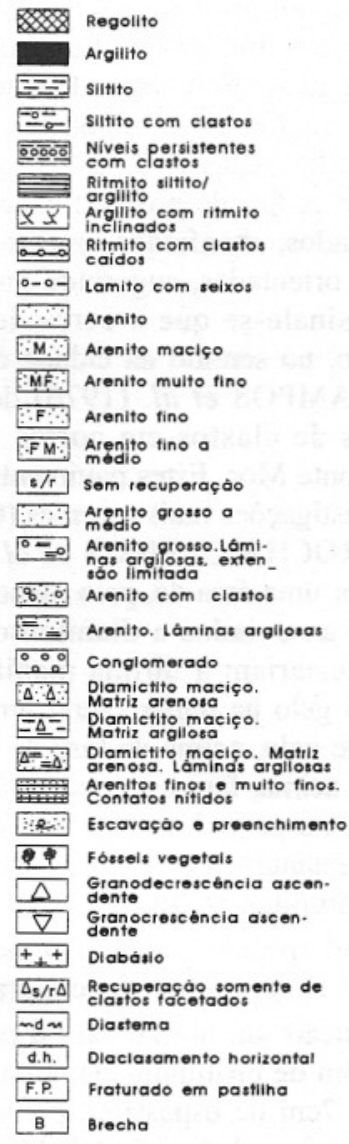

FIGURA 4A - Legenda das seções geológicas dos poços, deste trabalho. 
depósitos expostos neste afloramento e em afloramentos próximos a ele, representaria processos de ressedimentação, essencialmente gravitacionais, através de inundação por transgressão marinha (GAMA JR. et al., 1992 a-b). Eles, portanto, deveriam ser referidos à Formação Capivari.

Os $28 \mathrm{~m}$ da seção pelítica basal do poço 2 se constituem em espessura mínima, visto que o poço foi interrompido nesta litologia. É interessante assinar que, antes de 1985, o IG-SMA perfurou dois poços, cerca de $5 \mathrm{~km}$ ao norte do poço 2. Estes poços, descritos pelo Geólogo Geraldo Hideo Oda, exibiram seções litológicas semelhantes às do poço 2 , ambos com seções pelíticas basais, com espessuras mínimas, respectivamente, de 120 e $70 \mathrm{~m}$, sucedidas por intercalações de arenito e siltito/argilito. Estes poços foram perfurados a profundidades maiores do que a do poço 2 , ou seja, 210 e $248 \mathrm{~m}$.

As litologias atravessadas pela sonda do poço 21 (FIGURA 5) exibem características dignas de nota. Após $3 \mathrm{~m}$ de regolito, a sonda cortou cerca de $2 \mathrm{~m}$ de ritmitos "tipo Itu" e depois, cerca de 4,4m de diamictito maciço, de matriz arenosa, com clastos caoticamente dispostos, angulosos, facetados, de litologias variadas, chegando a $8 \mathrm{~cm}$ de diâmetro. A $6 \mathrm{~m}$ de profundidade, os clastos estão aplainados, chanfrados na parte superior e com estrias orientadas, sugerindo pavimento de clastos. Assinale-se que a cerca de $1,8 \mathrm{~km}$ do mesmo poço, no sentido da cidade de Capivari, ROCHA-CAMPOS et al. (1976) descreveram pavimentos de clastos em cortes da rodovia Capivari-Monte Mor. Estes pavimentos, de acordo com investigações mais recentes (COTTER et al., 1992; ROCHA-CAMPOS et al., 1992), se estendem por uma área de, pelo menos, 5 x $2 \mathrm{~km}$, usualmente associados a diamictito de matriz arenosa. Atestariam a última manifestação da atividade do gelo na região; seria uma flutuação de avanço de gelo, acima da fase de afogamento mencionada acima, fase esta que teria propiciado a deposição, no poço 21 , dos $150 \mathrm{~m}$ de sedimentos, predominantemente pelíticos, ritmitos (siltito/argilito), argilitos e siltitos.

O referido pacote de $150 \mathrm{~m}$ de pelitos, exibe deformações em certos níveis, em grau elevado.

Em posição sub-horizontal ou pouco deformada até $34 \mathrm{~m}$ de profundidade, adquire posição vertical por $7 \mathrm{~cm}$ de espessura, passando, novamente à posição sub-horizontal. Mais abaixo, a $41,3 \mathrm{~m}$ adquire posição inclinada.

A partir de $49 \mathrm{~m}$, a disposição dos estratos se torna complicada, ora com atitudes verticais, ora inclinadas, ora arranjadas em dobras apertadas, cortadas por grande número de pequenas falhas, dispostas em diversas direções, com

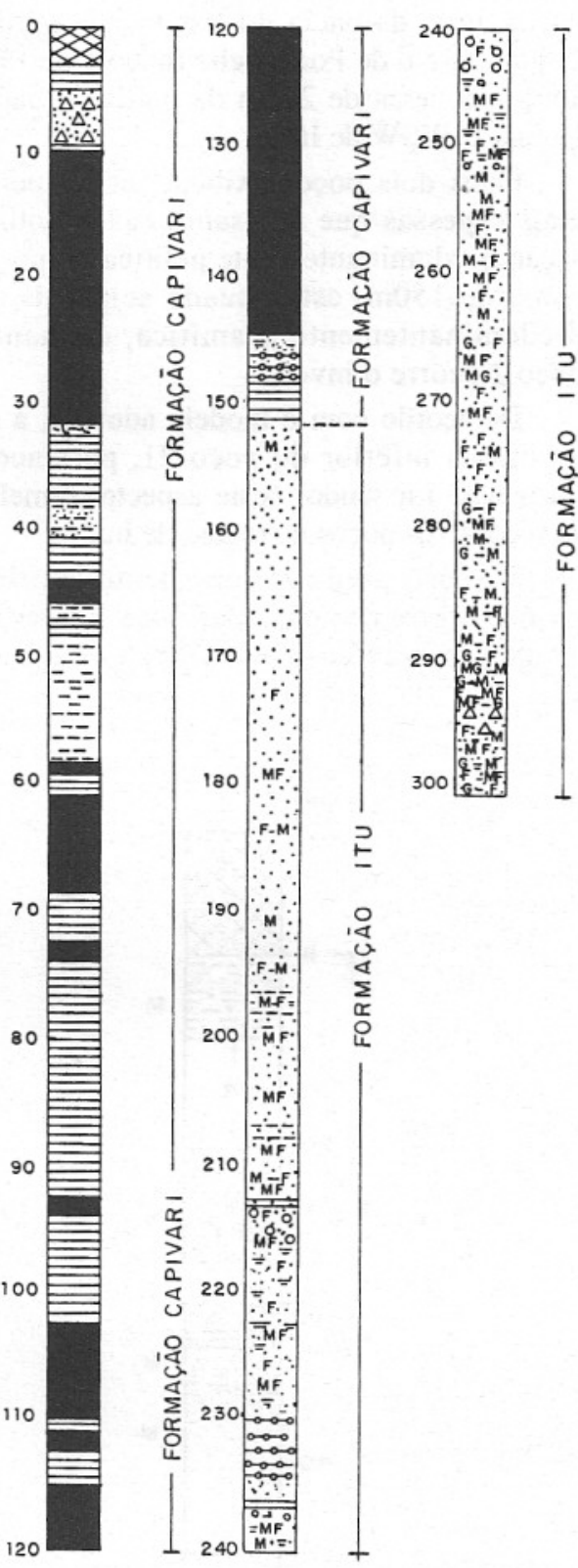

FIGURA 5 - Seção geológica de poço $n^{\circ} 21$.

rejeitos milimétricos, como por exemplo, no intervalo 68,5 a 69m (FOTO 1).

As deformações vão se acentuando até que, de 74 a $75 \mathrm{~m}$, os estratos estão com a base e o topo invertidos (FOTO 2).

Abaixo de $75 \mathrm{~m}$, os estratos estão ora verticais ora inclinados, fraturados, com contatos denteados por falhamentos complexos, às vezes com dobras se desmanchando em fragmentos irregulares devido à grande quantidade das mencionadas falhas que são de pequenos rejeitos (FOTO 3). Às vezes os estratos passam de subhorizontais para verticais (FOTO 4). 


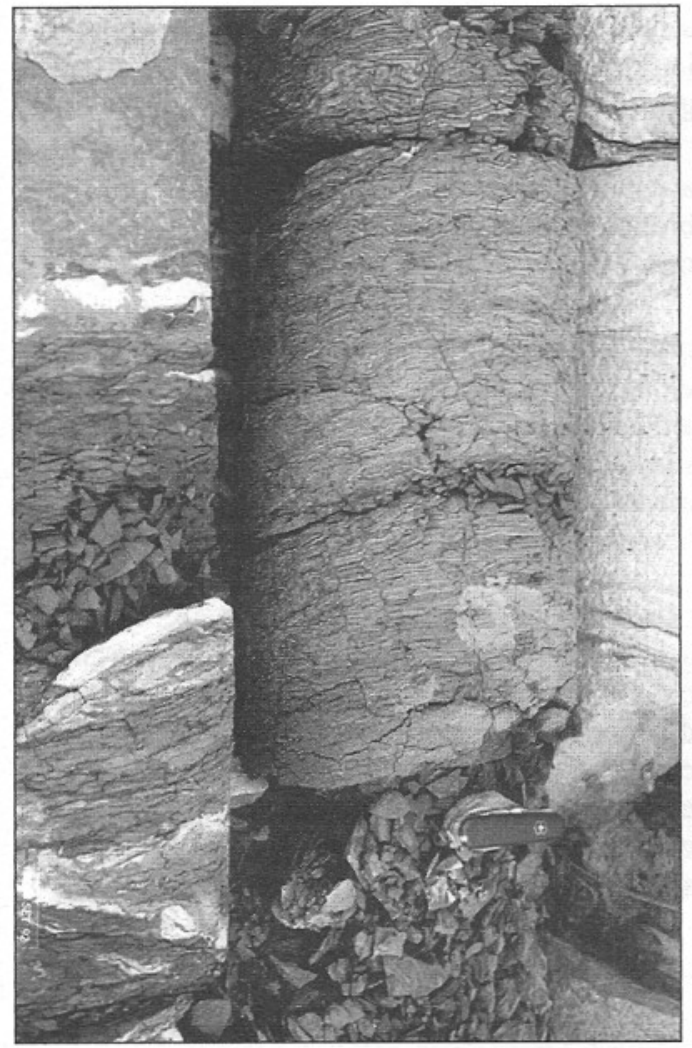

FOTO 1 - Poço 21 , a $69 \mathrm{~m}$ de profundidade. Lâminas amarrotadas, cortadas por grande número de pequenas falhas.

A partir de $87 \mathrm{~m}$ até $89 \mathrm{~m}$, os estratos são verticais, com ondulações regulares compressionais, que poderiam ser de origem sedimentar ou tectônica (FOTO 4).

A partir de $90 \mathrm{~m}$, os estratos exibem perturbações de intensidade relativamente menores (FOTO 5).

De todos os poços da região do médio Tietê, este é o que apresenta perturbações mais marcantes. A existência de espessos pacotes de sedimentos revolvidos in totum excluiria, a nosso ver, a hipótese de sismitos. Além disso, deslize ao longo de uma rampa pronunciada, causada pelo próprio processo de sedimentação é característica comum em sedimentos depositados através de deglaciação, visto que o gelo é o mais enérgico agente erosivo que se conhece. Estas feições, conhecidas na literatura como glaciotectônicas, são citadas em muitas ocorrências mundiais em depósitos originados por deglaciação. Possível tectonismo concomitante com a deposição dos sedimentos Itararé ou pós Itararé, só poderia ser esclarecido por estudos pormenorizados das direções de falhamentos em âmbito regional.
Em suma, as litologias atravessadas pelos poços do grupo I, se distribuem, estratigraficamente, de acordo com as interpretações adotadas, ou seja, uma formação basal, não marinha, predominantemente arenosa, transgressiva, Formação Itu, seguida de deposição psamítica e pelítica, em ambiente marinho, reunidas na Formação Capivari. No limite entre as duas formações, há grande desenvolvimento de pelitos (PETRI, 1992; PETRI \& PIRES, 1992). Espacialmente estas duas formações devem ser parcialmente contemporâneas formando sistemas deposicionais.

Considerando-se os poços perfurados pelo IG-SMA desde 1985, os mais orientais são os de $\mathrm{n}^{\circ} 1$ (It-85) e 21 (C2-92). Entre o poço 21 e os da região Capivari-Rafard, ocorre uma área sem perfurações: os poços da região CapivariRafard estão concentrados no lado ocidental da região (FIGURA 2). Fica-se, assim, com deficiência de amostragem para relacionar os poços da região oriental com os da região CapivariRafard.

A região mais conhecida a leste do poço 21 é a de Campinas, onde se encontram infor-

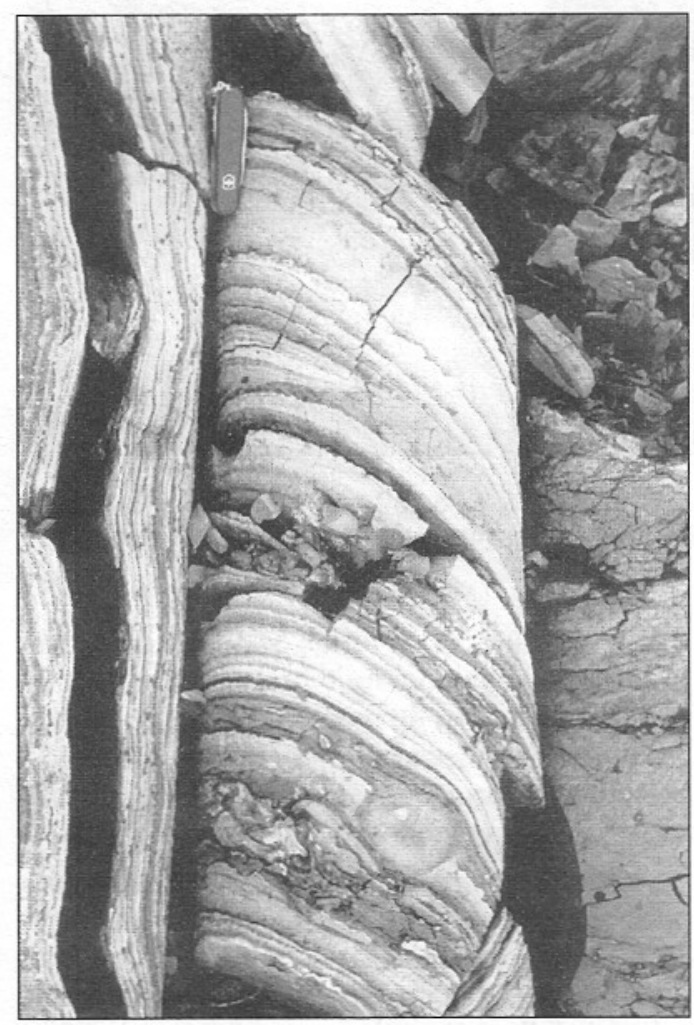

FOTO 2 - Poço 21 , a 74,5m de profundidade. Topo e base das camadas invertidos, reconhecíveis pelas sobrecargas. À esquerda, aparece parte do testemunho de $88 \mathrm{~m}$ de profundidade, onde os estratos possuem atitude vertical. 
mações em SAAD (1977); SOUZA FILHO (1986); FERNANDES et al. (1992 a-b). Estes últimos autores mapearam, pormenorizadamente, a porção sul da Folha de Campinas(SF 23-Y-A-j-4) e porção nordeste da Folha de Indaiatuba (SF-23-Y-C-II-2), na escala 1:50.000. De grande interesse para o estudo comparativo desta região com a de Capivari/Rafard são as seguintes informações provenientes deste trabalho.

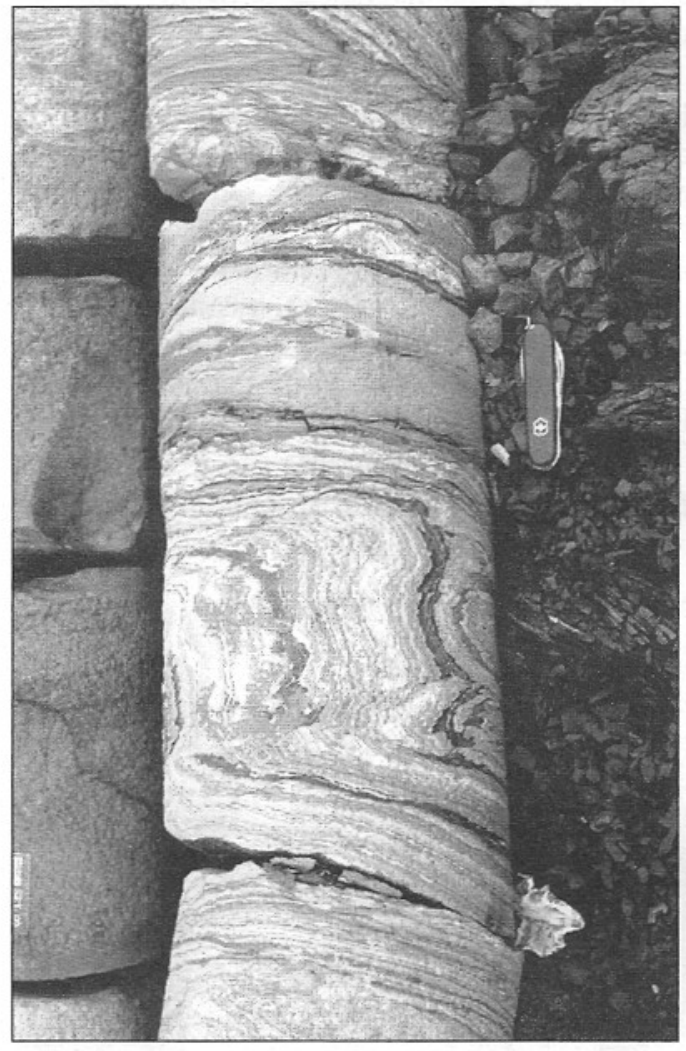

FOTO 3 - Poço 21, a 79m de profundidade. Passagem de estratos sub-horizontais para verticais.

A - Existência de tilitos de alojamento diretamente em contato com o embasamento cristalino. São maciços, de matriz argilosa, tabulares, de dimensões métricas, com clastos facetados, de tamanho variado, grânulos, seixos e até matacões, alguns estriados, de litologias variadas.

Contêm camadas lenticulares de arenitos finos até grossos, com seixos, laminação cruzada e com intraclastos de lamito na base. A superfície de contato é bastante irregular e cortado por falhas que atingem o sedimento acima do embasamento.

Os tilitos de alojamento passam acima para diamictitos estratificados, matriz argilosa e lamitos estratificados em camadas decimétricas a métricas. Associados aos diamictitos ocorrem lamitos estratificados, conglomerados e arenitos grossos.

B - Ritmitos não diretamente relacionados aos diamictitos foram interpretados como turbiditos proximais do tipo TABCDE e distais do tipo TDE.

C - Arenitos associados ou não a conglomerados, ocupando a base de estruturas de corte e preenchimento, de dimensões métricas, matriz arcosiana, também ocorrem. Arenitos mais finos são subordinados. Ocorrem cortes e preenchimentos de dimensões métricas, estratificações acanaladas, intraclastos de argilito e siltito, granodecrescências ascendentes e descendentes, camadas métricas lenticulares de arenitos com acamamento, laminações cavalgantes, arenitos com megaintraclastos decimétricos a métricos de arenito fino, argiloso, laminação convoluta e camadas métricas de arenito maciço, estratificação cruzada tabular de grande e médio portes e estratificações plano-paralelas de arenitos de seleção moderada a má, feldspáticos.

D - Arenitos finos a médios com estratificação sigmoidal, relativamente bem seleciona-

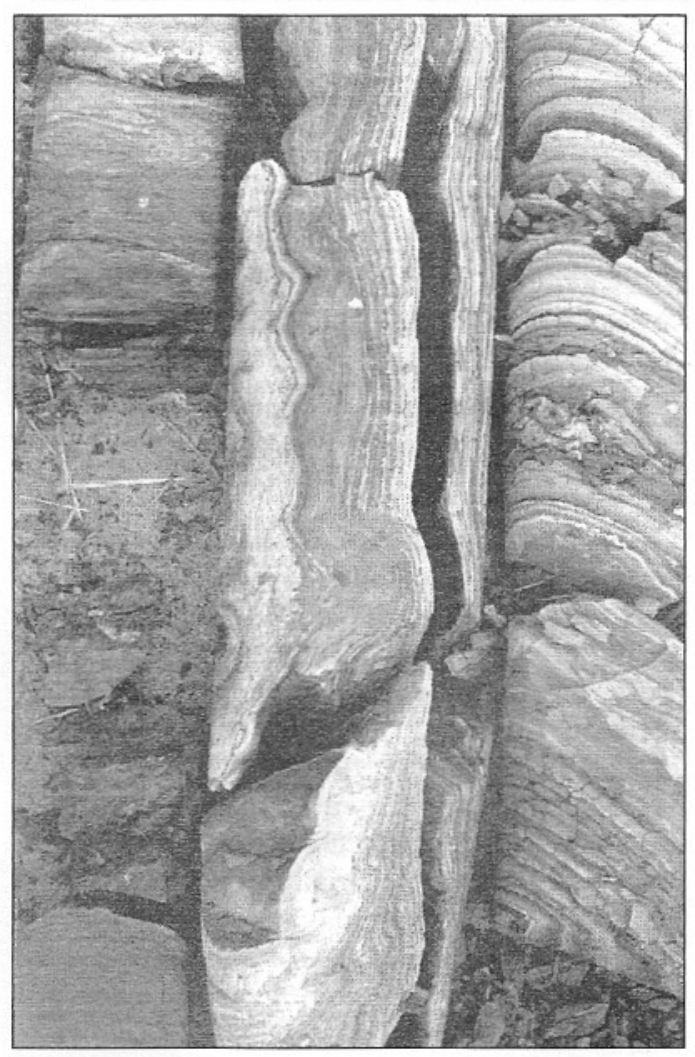

FOTO 4 - Poço 21, a $88 \mathrm{~m}$ de profundidade. Estratos verticais, exibindo à esquerda ondulações regulares compressionais, e à direita parte do testemunho de $74,5 \mathrm{~m}$ de profundidade, com topo e base invertidos. 
dos, maciços e homogêneos mas, ocasionalmente com estratos centimétricos a milimétricos de arenito médio a fino ou lâminas de arenito fino, escuro, que delimitam estratificações métricas sigmoidais. Ocorrem como corpos lenticulares justapostos de dimensões métricas. Associam-se arenitos idênticos com estratificações cruzadas acanaladas métricas a decimétricas, festonadas, com marcas onduladas. Megaintraclastos de arenito laminado também ocorrem.

As ocorrências do Itararé desta região oriental foram aqui expostas com duas finalidades: a - ressaltar as características mais claramente subaéreas em relação às de CapivariRafard; b - ressaltar certas semelhanças com as regiões também orientais, isto é mais próximas às bordas da bacia de Itu, Salto de Pirapora (MASSOLI, 1991) e Pilar do Sul (PELLOGGIA \& BERGMANN, 1992).

Assim, a litofácies A da região de Campinas deve ser de origem continental, depositada diretamente pelo gelo ou água de degelo. Os ritmitos da litofácies B poderiam corresponder a sedimentos lacustres represados pela sedimentação glacial.

As litofácies englobadas em C, corresponderiam a depósitos fluviais alimentados por

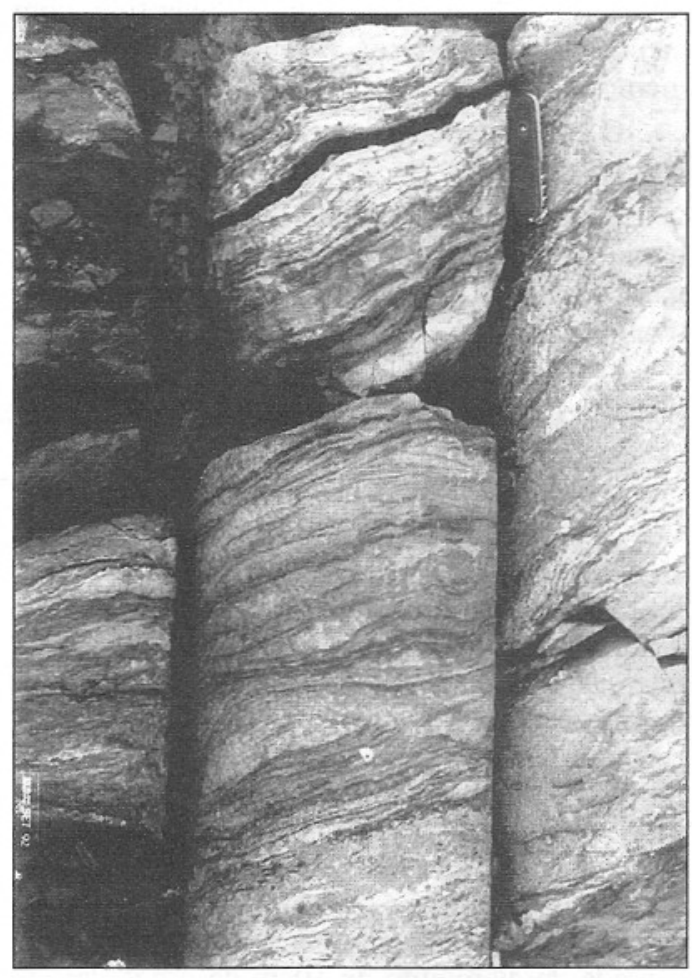

FOTO 5 - Poço 21, a 90m de profundidade. Perturbações menos intensas em relação aos estratos superiores. geleiras e que, gradativamente formariam os sedimentos deltáicos da litofácies D.

Inflelizmente, não foram possíveis estudos pormenorizados para estabelecer as relações destes deltáicos com os marinhos de Hortolândia, descobertos por ROCHA-CAMPOS \& RÖSLER (1975 apud SAAD, 1977). Os sedimentos que aparecer na região Capivari/Rafard, corresponderiam a mares costeiros com relacionamento mais afastado com os sedimentos não marinhos da região de Campinas. Os poços deste subgrupo $\left(\mathrm{n}^{\circ} 2\right.$ e 21$)$ têm seus perfis aqui publicados.

$O$ poço $\mathrm{n}^{\circ} 2$, com apenas $80 \mathrm{~m}$ de profundidade, exibiu capacidade específica de $0,04 \mathrm{~m}^{3} / \mathrm{h} / \mathrm{m}$ e o $21 \mathrm{com} 300 \mathrm{~m}$ de profundidade, exibiu produção bem superior $\left(0,45 \mathrm{~m}^{3} / \mathrm{h} / \mathrm{m}\right)$ por ter atingido porções mais arenosas.

\section{3 - Grupo II - Região Capivari/Rafard}

As características litológicas dos poços deste grupo foram discutidas em diversos trabalhos (PETRI, 1992; PETRI \& PIRES, 1992; PETRI et al., 1996). Todas as observações até agora convergem para o modelo de fluxo de detritos provenientes de uma borda continental situada a nordeste, além da atual Rodovia do Açúcar, que liga Capivari à Piracicaba e avançando para sudoeste. A transgressão marinha teria vindo de sudoeste para nordeste embora, atualmente, o mergulho regional seja para noroeste, o que seria tectônico.

A predominância de psamitos, incluindo freqüências menores de psefitos com relação aos pelitos, na maioria dos poços do município de Capivari, conduziu a interpretação de fluxos de detritos amalgamados (PETRI et al., 1996).

Os poços do município de Rafard mostram freqüências maiores de pelitos do que os de Capivari, o que se conforma com o modelo de sedimentação admitido para a área.

As colunas litológicas dos seguintes poços, perfurados no município de Capivari, foram descritas em trabalhos anteriores (fig. $\mathrm{n}^{\circ} 2$, tabela 1): poço 7, 9, 11, 12, 13 (PETRI, 1992); (fig. 4): poço 22 (PETRI et al., 1996). A localização dos poços da região de Capivari encontra-se na fig. 2 deste trabalho onde estão especificadas as proporções de clásticos grossos (psamitos mais psefitos) em relação aos finos (pelitos). Pelo exame desta figura, verifica-se que as porcentagens de clásticos grossos aumentam para o norte, o que está de acordo com o modelo adotado.

Neste artigo é descrito o poço de número 21. Encontram-se, ainda, com colunas litológi- 
cas não publicadas, os poços de números 14,15 , $19,20,27$ e 31 .

Os 16 poços das zonas urbanas Capivari / Rafard apresentaram capacidade específica de $0,65 \mathrm{~m}^{3} / \mathrm{h} / \mathrm{m}$ (TABELA 2 ).

TABELA 2 - Poços de Capivari/Rafard e de Tietê: capacidade específica média $\left(\mathrm{m}^{3} / \mathrm{h} / \mathrm{m}\right)$ relacionadas com a espessura média de psamitos.

\begin{tabular}{|c|c|c|}
\hline & $\begin{array}{l}\text { CAPIVARI/ } \\
\text { RAFARD }\end{array}$ & TIETÊ \\
\hline $\begin{array}{l}\text { Profundidade } \\
\text { média dos } \\
\text { poços }\end{array}$ & $\begin{array}{l}272.23 \mathrm{~m} \\
17 \text { poços }\end{array}$ & $\begin{array}{l}293.67 \mathrm{~m} \\
6 \text { poços }\end{array}$ \\
\hline $\begin{array}{l}\text { Espessura } \\
\text { média de } \\
\text { Psamitos } \\
\text { (m) }\end{array}$ & $\begin{array}{l}189,72 \mathrm{~m} \\
17 \text { poşos }\end{array}$ & $\begin{array}{l}153,17 \mathrm{~m} \\
6 \text { poços }\end{array}$ \\
\hline $\begin{array}{l}\text { Capacidade } \\
\text { especifica medla } \\
\left(\mathrm{m}^{3} \mathrm{~m} / \mathrm{m}\right)\end{array}$ & $\begin{array}{c}0,65 \mathrm{~m} \\
16 \mathrm{pocpos}\end{array}$ & $\begin{array}{l}1,08 \mathrm{~m} \\
6 \text { poços }\end{array}$ \\
\hline
\end{tabular}

\subsection{Grupo III - Região de Tietê}

Menor número de poços foi perfurado pelo IG-SMA desde 1985, nesta região, em relação a de Capivari-Rafard (FIGURA 3), sendo sete na cidade de Tietê, dois no distrito de Jumirim e dois no distrito de Sete Fogões. Há, ainda, um poço particular perfurado em Tietê, com perfil litológico descrito.

Os sete poços perfurados em Tietê exibiram comportamentos mais variados do que os da região Capivari/Rafard. A maioria destes poços encontrou intrusões de diabásio de espessuras variadas. Nenhum dos poços perfurados em Capivari-Rafard encontrou diabásio. Só um poço da cidade de Tietê, o de $\mathrm{n}^{\circ} 16$, não encontrou diabásio.A seção geológica do poço $\mathrm{n}^{\circ} 17$, contém $216 \mathrm{~m}$ de diabásio. O IG-SMA perfurou $137 \mathrm{~m}$ neste poço, o restante foi perfurado por firma particular quando, então, o poço atingiu $300 \mathrm{~m}$ de profundidade. Delgado corpo de arenito foi atravessado no fundo do poço. A espessura de sedimentos acima do diabásio foi de $83,5 \mathrm{~m}$. Este poço, portanto, não pode ser considerado representativo em termos de porcentagem de clásticos grossos, $60 \%$, devido ao diabásio. Desconsiderando este poço, verifica-se para a região de Tietê, aumento da porcentagem de clásticos grossos para sudeste. A consideração dos poços de Sete Fogões a leste de Jumirim, a oeste, mostra que esta tendência se mantém no sentido oeste-leste, o que se considera normal, tendo em vista que as condições vão ficando mais enérgicas a leste, rumo à borda da bacia.

O poço $\mathrm{n}^{\circ} 28$, também cortou espessura apreciável de diabásio, $35,4 \mathrm{~m}$, tendo sido inter- rompido nesta litologia. Acima do diabásio foram perfurados $226,6 \mathrm{~m}$ de sedimentos, tendo sido possível, portanto, informações representativas a respeito das porcentagens de clásticos grossos, que ocorreu dentro do esperado (FIGURA 3) e com diamictitos predominantes na seção superior (até $90 \mathrm{~m}$ ).

Os diamictitos dos poços da região de Tietê, quando ocorrem em espessuras apreciáveis, se situam na parte superior. Os poços 10 e 23 , a este respeito, podem ser tomados como exemplos. Nas curvas de raios gama, aparecem como serrilhados, com avanços e recuos, devido à heterogeneidade litológica (PETRI et al., 1996).

O poço $n^{\circ} 10$ (FIGURA 6), possui as seguintes características: a) grande espessura de diamictitos principalmente arenosos; b) freqüência de restos de plantas em certos intervalos; c) com exceção dos diamictitos, as outras litologias são menos espessas, havendo maiores variações litológicas em relação aos poços da área Capivari/Rafard; d) freqüentes diastemas; e) a coluna litológica do poço pode ser dividida em uma série de intervalos, numerados debaixo para cima.

$\mathrm{O}$ intervalo I caracteriza-se por ritmito (siltito/argilito), ambiente de águas calmas que passa, acima ao intervalo II, arenito mal selecionado, de muito fino a conglomerático, com ou sem filmes argilosos, de ambiente mais enérgico.

O intervalo III caracteriza-se por grau de energia variável.

O intervalo IV, constituído de ritmitos contendo delgadas intercalações de diamictitos de matriz argilosa, sugere ambiente predominantemente calmo.

$\mathrm{O}$ intervalo $\mathrm{V}$ se constitui em continuação do IV, com ritmitos contendo delgadas intercalações de diamictitos de matriz argilosa; ambiente predominantemente calmo.

O intervalo VI se sucede, gradativamente, ao $\mathrm{V}$, através de diamictito de matriz argilosa. Este intervalo é predominantemente constituído de diamictito de matriz arenosa, com delgadas intercalações de ritmito e siltito. Ambiente predominantemente enérgico com fases de águas calmas. Diastemas são freqüentes: a $13 \mathrm{~m}$ de profundidade, ocorre um diastema reconhecido pelo contato de um diamictito com matriz lamítica passando a arenosa, com clastos e intraclastos de siltito, assentando sobre siltito do mesmo tipo dos intraclastos. A $34 \mathrm{~m}$, ocorre uma camada de diamictito de $10 \mathrm{~cm}$ de espessura, de matriz arenosa, com clastos angulosos e facetados. Acima, em contato ondulado, ocorre ritmito de arenito fino e de filmes sílticos e abaixo 
ocorre outra camada de diamictito de matriz arenosa e seixos facetados, separada do primeiro diamictito por uma camada de arenito muito fino, rica em filmes sílticos. A $44 \mathrm{~m}$, diamictito de matriz arenito feldspático e com seixos angulosos e facetados assenta, em contato ondulado, sobre arenito muito fino que por sua vez assenta sobre outra camada de diamictito de matriz arenosa. A 92m, ocorre diamictito maciço, contendo uma grande lente de arenito conglomerático, em contato ondulado acima e abaixo com o referido diamictito. A $101 \mathrm{~m}$, siltito em contato superior e inferior com arenito com pequenos grânulos. $\mathrm{O}$ contato do arenito acima com o siltito é muito irregular, este se mostrando escavado e preenchido pelo arenito.

As freqüentes variações de litologias, a ocorrência de abundantes restos de plantas terrestres carbonizadas no intervalo IV e a abundância de diastemas são características que sugerem ambientes costeiros de deposição, eventualmente, em certos intervalos, ambientes não marinhos.

O poço $n^{\circ} 23$ (FIGURA 7), exibe dois pacotes bem distintos, separados à profundidade de $151 \mathrm{~m}$. A base do pacote inferior, até a profundidade de $185 \mathrm{~m}$, exibe algumas sucessões de granodecrescências, a partir de sedimentos arenosos para argilosos. Seus sedi-

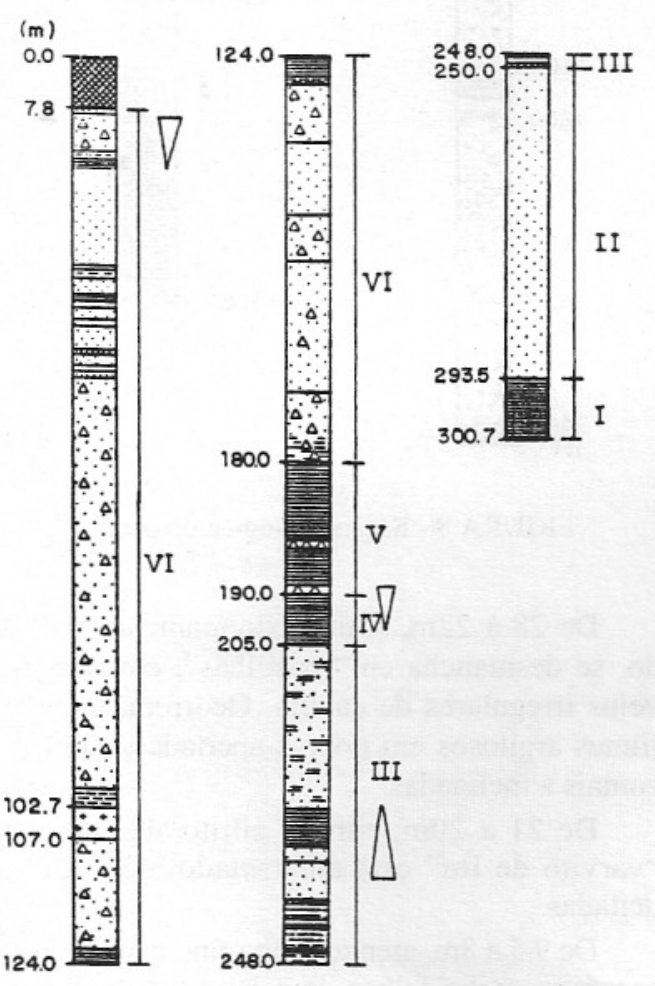

FIGURA 6 - Seção geológica do poço $n^{\circ} 10$.

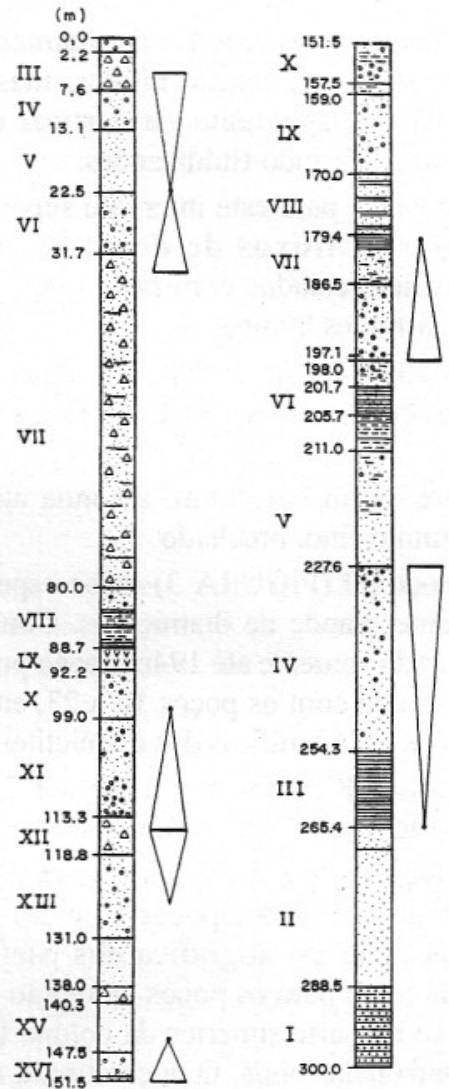

FIGURA 7 - Seção geológica do poço $\mathrm{n}^{\circ} 23$.

mentos exibem, comumente, laminação planohorizontal.

Da base do poço, a $300 \mathrm{~m}$ até $288,5 \mathrm{~m}$, ocorre uma sucessão de camadas de arenitos finos e muito finos, em contatos nítidos, com boa separação granulométrica de seus termos.

Embora arenitos predominem neste intervalo inferior, sedimentos finos (ritmitos, siltitos, lamitos), são freqüentes. Os contatos entre as litologias são nítidos. Foi possível reconhecer granodecrescência ascendente, de 197,1 a 175,4m, limitada na base, por um diastema, com ritmito abaixo da superfície do diastema e arenito grosso acima. Não ocorrem diamictitos nesta seção inferior.

O pacote acima de $151,5 \mathrm{~m}$ exibe elevada porcentagem de diamictitos. Eles são maciços, de matriz arenosa, com clastos facetados de diversas litologias. Intercalam-se com delgados corpos de arenitos finos mas com grânulos de alguns clastos maiores. A freqüência de clastos, às vezes, aumenta até se transformar em um diamictito lenticular. Há intercalações de conglomerados e arenitos conglomeráticos.

Alguns clastos dos diamictitos exibem feldspatos aparentemente sem alterações e biotitas ainda com a cor original. 
Os contatos dos corpos de diamictitos e de arenitos são, via de regra, nítidos, mas há passagens irregulares, tanto na vertical como na horizontal, sugerindo fluidizações.

Sugere-se, para este intervalo superior, ação freqüente de fluxos de detritos em mares costeiros, intercalados com fases onde predominariam correntes laminares.

Em ambos os intervalos deste poço, falhas normais com rejeitos milimétricos são freqüentes.

Entre $133 \mathrm{~m}$ e $132,8 \mathrm{~m}$, a sonda atravessou arenito muito fino, brechado.

O poço 30 (FIGURA 3) exibe espessura relativamente grande de diamictitos. Contudo, ele foi perfurado somente até $194 \mathrm{~m}$, razão porque não foi comparado com os poços 10 a 23, em relação às posições estratigráficas dos diamictitos.

O poço 28 só foi perfurado até $258 \mathrm{~m}$. Os psefitos são pouco representativos.

O poço 18 , possui psefitos com espessuras menores do que as dos poços 10 e 23 . Também aqui a posição estratigráfica dos psefitos está dentro da regra para os poços da região de Tietê. Situam-se na parte superior da coluna litológica atravessada pela sonda. $\mathrm{O}$ poço atingiu a profundidade de 299,5m. Diamictitos ocorrem somente nos seguintes intervalos: $114-113 \mathrm{~m} ; 98-90 \mathrm{~m}$ e $38-22 \mathrm{~m}$.

Os poços 16 e 17 são os que se situam mais a sudoeste da área em torno da cidade de Tietê. $\mathrm{O}$ poço 17 não pode ser comparado com os outros porque exibe espessura de diabásio de, aproximadamente, $210 \mathrm{~m}$.

O poço 16 (FIGURA 8) é anômalo por exibir grande espessura de pelitos e pequena espessura de psefitos. Os sedimentos atravessados pela sonda neste poço exibiram grandes perturbações.

De 206 a $193 \mathrm{~m}$ foram encontrados siltitos escuros contendo lâminas amarrotadas de arenito muito fino. De 141,6 a 135,8, o sedimento é cortado por diversas falhas de rejeitos milimétricos, em diferentes direções. De 123 a $118 \mathrm{~m}$, intercalações de arenitos finos, siltitos e argilitos, exibem uma série de falhas de pequenos rejeitos com drags dos sedimentos finos.

Siltitos carbonosos e argilitos intercalados, no intervalo de 50 a $50,5 \mathrm{~m}$, exibem forte diaclasamento horizontal imprimindo à rocha aspecto de folhelho.

Também a $32 \mathrm{~m}$, pequenas intercalações de siltito muito fraturado tomam aspecto de folhelho.

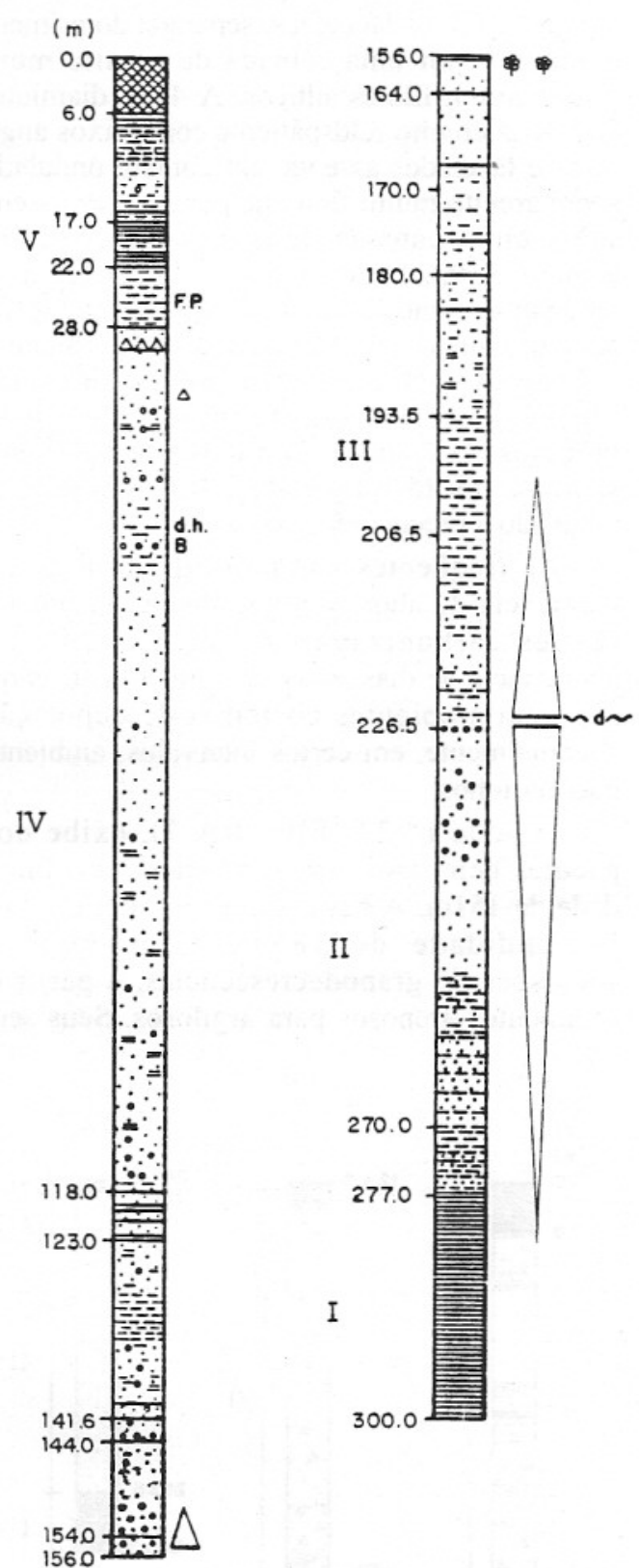

FIGURA 8 - Seção geológica do poço nº 16.

De 28 a $22 \mathrm{~m}$, siltito extremamente fraturado, se desmancha em "pastilhas", cortadas por veios irregulares de calcita. Ocorrem, também, filmes argilosos em dobras apertadas, sub-horizontais a inclinadas.

De 21 a $20 \mathrm{~m}$, ritmito siltito/argilito, tipo "varvito de Itu" está amarrotado, com dobras deitadas.

De 9,5 a 8m, arenito muito fino com grânulos esparsos, exibe falhas de rejeitos milimétricos, dispostas em direções convergentes, em cunha. 


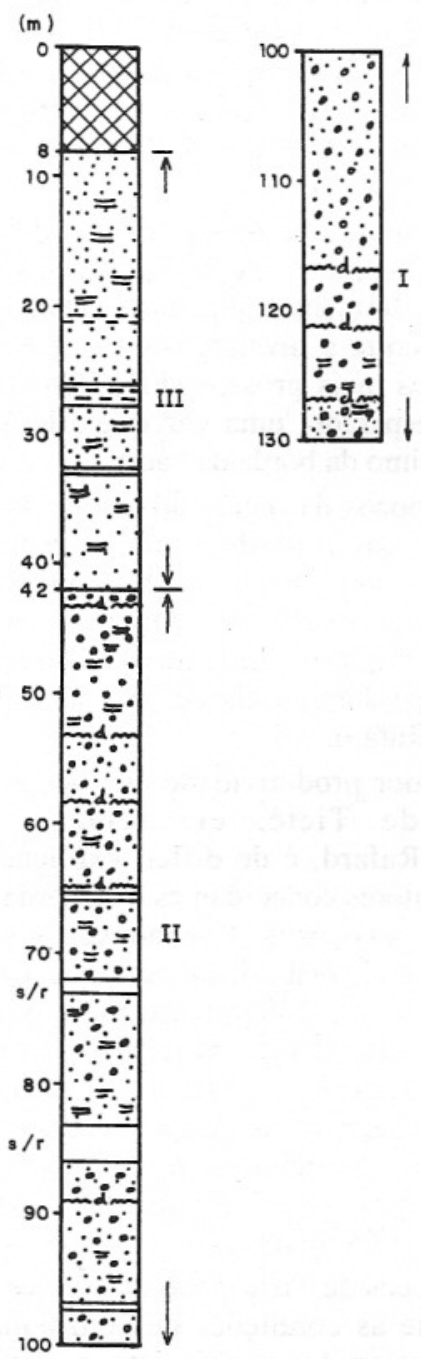

FIGURA 9 - Seção geológica do poço $n^{\circ} 5$.

A espessura de pelitos é relativamente grande, predominando sobre os psefitos. Alguns pelitos da seção superior do poço são lamitos com seixos (17-6m). Os diamictitos são sempre de pequena espessura, embora o do intervalo $156-154 \mathrm{~m}$ contenha até grandes clastos de granito cinza e quartzito, eventualmente com dimensões acima de calhaus, cortados pela sonda. Embora sempre de espessuras pequenas, os psefitos mais grossos caracterizam o pacote superior do poço (156-28m; intervalo IV). No pacote inferior, os psefitos são bem subordinados; não ocorrem diamictitos. A este respeito, este poço se assemelha aos poços típicos da área de Tietê, supramencionados.

Outras características do poço 16 , consideradas típicas da área de Tietê, são as seguintes: a) freqüência de granodecrescências ascendentes e descendentes; b) boa separação granulométrica dos estratos; c) presença de laminação cruzada por migração de marcas onduladas, sugestivas de correntes laminares, ultrapassando, em freqüência, as sugestivas de fluxos de detritos; d) relativa freqüência de leitos carbonosos e restos de vegetais carbonizados; e) a $226,5 \mathrm{~m}$, ocorre uma camada de $10 \mathrm{~cm}$ de conglomerado com seixos de quartzito branco, separando uma seção inferior com granocrescência ascendente e uma superior também com granodecrescência ascendente.

Os dois poços perfurados no distrito de Sete Fogões foram relativamente rasos $(130 \mathrm{~m}$ no poço 5 e $160 \mathrm{~m}$ no poço 24). As colunas litológicas de ambos são muito parecidas. Aqui será reproduzida a coluna geológica do poço $\mathrm{n}^{\circ} 5$ à guisa de exemplo (FIGURA 9).

Predominam arenitos finos a médios nas seções de ambos os poços, estando bem subordinadas outras litologias. Finas intercalações argilosas ocorrem com freqüência variável. Diamictitos estão ausentes. No poço $\mathrm{n}^{\circ} 24$ ocorre um conglomerado de 110,8 a $109,5 \mathrm{~m}$, sustentado por clastos. Alguns clastos ultrapassam $15 \mathrm{~cm}$ de diâmetro.

Apesar da predominância de arenitos, no poço $\mathrm{n}^{\circ} 5$, aqui tomado como exemplo, podem ser reconhecidos três pacotes litológicos.

I - 130-100m - Arenitos muito grossos a médios, com intercalação irregulares de arenito fino e de filmes argilosos. A ocorrência de filmes argilosos, geralmente de pequena extensão lateral, é sugestiva de erosão de antigos depósitos delgados de argilito e redeposição em ambientes mais propícios à deposição de clásticos mais grossos.

II - 100-42m - Arenitos predominantemente finos a muito finos, embora arenitos grossos, muito grossos e até conglomeráticos comparecem com certa freqüência. A $58 \mathrm{~m}$ de profundidade, ocorre uma estrutura de corte e preenchimento, com erosão de um arenito grosso, mas com muita matriz de arenito fino abaixo e deposição de arenito muito grosso com grânulos acima. Entre 64,5 e $65 \mathrm{~m}$, ocorre ritmito com pequenas estruturas lembrando microhummocky, assentado sobre arenito grosso. A $89 \mathrm{~m}$, ocorre arenito grosso, maciço, passando acima através de uma superfície irregular, para arenito conglomerático, passando acima para arenito fino através de granodecrescência.

III - 42-08m - Arenitos muito finos, com intercalações argilosas. Mais subordinadamente, aparecem ritmitos mas sempre intercalados em camadas argilosas espessas. Apenas duas ocorrências de siltito, com menos de $0,50 \mathrm{~m}$, foram registradas.

Observa-se tendência a diminuição de granulação dos arenitos da base para o topo do poço. 
É dificil sugerir ambientes de sedimentação a partir de testemunhos de dois poços, mas a ocorrência de granodecrescência ascendente, a partir de arenitos muito grossos a grossos, depressões preenchidas por arenitos muito grossos, freqüência de diastema, cosets de estratificações cruzadas acanaladas e tangenciais, fluidificações e variações granulométricas nítidas dos arenitos, sugere ambientes não-marinhos.

\section{5 - Grupo IV - Município de Mombuca}

O único poço deste grupo, o de número 4, teve seu perfil litológico publicado em PETRI (1992). É o único poço de todos os perfurados pelo IG-SMA, a partir de 1985 (portanto com descrição de perfil litológico e coleta de testemunhos), que exibe maior porcentagem de psefitos em relação aos psamitos. Distingue-se dos poços da região II (Capivari-Rafard) pela maior porcentagem de pelitos em relação aos psamitos, com exceção do poço 13, que também exibe este comportamento. É, ainda, o que apresenta maior espessura de diamictitos em relação a todos perfurados pelo IG-SMA desde 1985. Suas características permitiram sua individualização em relação aos outros poços.

O poço $n^{\circ} 4$, com baixa espessura de psamito (cerca de $41 \mathrm{~m}$ ) e com profundidade menor que a média dos poços estudados, apresentou capacidade específica relativamente boa $\left(0,34 \mathrm{~m}^{3} / \mathrm{h} / \mathrm{m}\right)$. Possui, contudo, espessura grande de diamictitos.

\section{DISCUSSÕES E CONCLUSÕES}

A TABELA 1 mostra que, de modo geral, as espessuras de psefitos são muito pequenas em quase todos os poços de Tietê, Jumirim e Sete Fogões, à exceção dos poços 8, 18, 23 e 30 .

As distintas condições paleogeográficas da região do médio Tietê, condicionaram a distribuição das diferentes litologias dos poços, em função das diferentes posições geográficas.

A área de Tietê se caracteriza por maior variabilidade de sucessões litológicas do que a de Capivari-Rafard.

Embora em Tietê os poços geralmente exibem diamictitos espessos e localizados nas suas seções superiores, em alguns poços eles são negligenciáveis, como visto para o caso do poço 16.

O poço particular, referido acima, na região de Tietê, situado ao norte dos demais, foi perfurados até a profundidade de $154 \mathrm{~m}$, tendo encontrado diabásio às profundidades de $13 \mathrm{e}$ $23 \mathrm{~m}$, de 60,5 a $63 \mathrm{~m}$ e 153 a $154 \mathrm{~m}$ (fim do poço). Como nos demais poços da cidade de Tietê, predominam os psamitos. A proporção de psefitos mais psamitos acompanha o quadro elaborado para a região.

Dentro da área de Tietê, a tendência para maior proporção de sedimentos finos ocorre a oeste, em Jumirim, enquanto a leste, em Sete Fogões, ocorre o inverso, isto é, tendência para sedimentos mais grossos (FIGURA 3), dentro aliás do esperado, uma vez que a leste se está mais próximo da borda da bacia.

Seis poços da região urbana de Tietê apresentaram capacidade específica média de $1,08 \mathrm{~m}^{3} / \mathrm{h} / \mathrm{m}$ (TABELA 2). De acordo com esta tabela, os poços de Tietê são, em média, mais produtivos que os de Capivari/Rafard e com menor espessura média de psamitos que os de Capivari/Rafard.

A maior produtividade dos poços da zona urbana de Tietê, em relação aos de Capivari/Rafard, é de difícil explicação, pois existem fatores concordantes e discordantes. Por exemplo, os poços de Tietê atravessaram menos psamitos, mais diabásios e estão localizados em uma região tectonicamente mais perturbada (calha do Rio Tietê), em relação aos poços de Capivari/Rafard. As fraturas em diabásio dos poços de Tietê parecem não representar fator importante em produtividade pois os poços com maiores espessuras de diabásio não são os mais produtivos (TABELA 1).

Os poços de Tietê e Rafard são semelhantes no tocante às condições de confinamento do terço inferior dos poços, isto é, entre 200 e

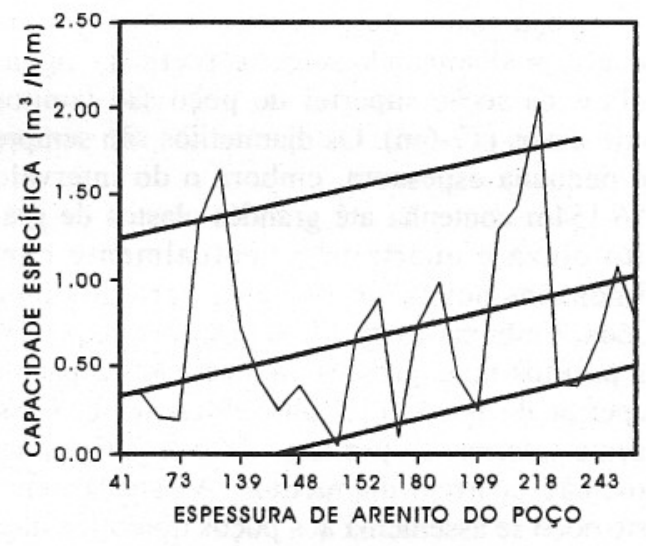

FIGURA 10 - Capacidade específica em função da espessura de arenito da seção geológica dos poços. 
300m. Em algum destes poços foi possível comprovar experimentalmente estes fatos, através dos testes de vazão intermediários (entre 150 a $200 \mathrm{~m}$ ), antes da conclusão final do poço. Em muitos casos foi observado aumento significativo da vazão nos testes finais de produção. Em Capivari esta situação nem sempre foi relevante, devido à maior quantidade de sedimentos mais finos nas partes mais profundas dos poços.

A grande concentração de intrusões de diabásio na região de Tietê sugere tectonismo mais intenso do que na região Capivari/Rafard, sugestão esta reforçada pelo traçado do rio Tietê (FIGURA 3).

Dentro da região de Tietê, a tendência para maior proporção de sedimentos finos ocorre a oeste, em Jumirim, enquanto a leste, em Sete Fogões, ocorre o inverso, isto é, tendência para sedimentos mais grossos (FIGURA 3), dentro aliás do esperado, uma vez que a leste se está mais próximo da borda da bacia.
$\mathrm{Na}$ análise da produtividade dos poços em relação às litologias atravessadas, verificou-se um acréscimo da capacidade específica com o aumento da espessura de psamitos de cada poço (FIGURA 10).

\section{AGRADECIMENTOS}

Os autores agradecem ao IG-SMA pelo apoio recebido e pela permissão de divulgar os resultados obtidos.

Ao Dr. Hung Kiang Chang, geólogo da UNESP de Rio Claro, nossos agradecimentos pelas fotos de testemunhos do poço 21 .

Temos, também, o prazer de deixar aqui expresso, nosso reconhecimento à Sra. Thelma M. Collaço Samara, da Seção de Reprodução Gráfica do Instituto de Geociências da USP, que sempre nos atendeu com a máxima gentileza.

Ao Instituto de Geociências da USP nossos agradecimentos pela acolhida que sempre nos devotou.

\section{REFERÊNCIAS BIBLIOGRÁFICAS}

BARBOSA, O. \& ALMEIDA, F.F.M. 1949. A Série Tubarão na Bacia do Rio Tietê, Estado de São Paulo. DNPM/DGM Notas Preliminares e Estudos $n^{\circ} 48,16 p$.

COTTER, J.F.P.; ROCHA-CAMPOS, A.C.; SANTOS, P.R. \& CANUTO, J.R. 1992. The origin of striated boulder pavements: envidence from Capivari, São Paulo, Brazil (Late Paleozoic) and the Minnesota river valley/USA Pleistocene. In: CONGRESSO BRASILEIRO DE GEOLOGIA, 37., 1992, São Paulo. Bol. Resumos, Simpósios. São Paulo: SBG, v.1, p. 522-524.

FERNANDES, A.J.; AZEVEDO SOBRINHO, J.M.; TEIXEIRA A.L.; BOGGIANI, P.C. \& GARDA, G.M. 1992. Geologia do município de Campinas (SP), São Paulo IGSMA, Relatório Interno, v. 2, p. 2-51.

FERNANDES, A.J.; AZEVEDO SOBRINHO, J.M. \& TEIXEIRA, A.L. 1992. O Subgrupo Itararé a sudeste de Campinas In: CONGRESSO BRASILEIRO DE GEOLOGIA, 37., 1992, São Paulo. Bol. Resumos, Sessões Temáticas. São Paulo: SBG, v. 2, p. 524-525.

GAMA JR., E.G.; PERINOTTO, J.A.J. \& RIBEIRO, H.J.P.S. 1991. Contribuição ao estudo de parasseqüências no Subgrupo Itararé (P-C) no Estado de São Paulo. In:
SIMPÓSIO DE GEOLOGIA DO SUDESTE, 2., 1991, São Paulo. Atas... Núcleos SP/RJ-ES: SBG, p. 385-389.

GAMA JR., E.G.; PERINOTTO, J.A.J.; RIBEIRO, H.J.P.S. \& PADULA, E.H. 1992a. Contribuição ao estudo da ressedimentação no Subgrupo Itararé: tratos de fácies e hidrodinâmica deposicional. Revista Brasileira de Geociências, 22(2): 228-236.

GAMA, JR., E.G.; PERINOTTO, J.A.J.; RIBEIRO, H.J.P.S. \& PADULA, E.H. 1992b. Contribuição ao estudo da ressedimentação no Subgrupo Itararé: um guia temático de campo. Revista Brasileira de Geociências, 22(2): 237-247.

MASSOLI, M. 1991. Relação entre o embasamento cristalino e os sedimentos basais do Subgrupo Itararé na região de Sorocaba-Salto de Pirapora, SP. São Paulo, Inst. de Geociências/USP, 94p. (Dissertação de Mestrado). Inédita.

PELlogGia, A.U.G. \& BERGMANN, M. 1992. Aspectos da Geologia do Subgrupo Itararé na região de Pilar do Sul (SP). In: CONGRESSO BRASILEIRO DE GEOLOGIA, 37., 1992, São Paulo. Bol. Resumos, Sessões Temáticas. São Paulo: SBG, v. 2, p. 522-523. 
PETRI, S. 1992. Litofácies e significado paleoambiental dos sedimentos Itararé na região Capivari-Rafard, Estado de São Paulo. São Paulo: SMA, Revista do Instituto Geológico, 13(1): 7-30.

PETRI, S. \& PIRES, F.A. 1992. O Subgrupo Itararé (Permiano-Carbonífero) na região do Médio Tietê, Estado de São Paulo. Revista Brasileira de Geociências 22(3): 301-310.

PETRI, S.; MENDONÇA, C.A.; BOLOGNA, M. de S.; COUTINHO, J.M.V.; VIEIRA, P.C. \& BOTELHO, P.F. 1996. Correlação estratigráfica de poços para captação de água subterrânea na região Capivari-Rafard/SP: descrições litológicas macroscópicas, microscópicas e perfis geofísicos. Revista Brasileira de Geociências 26(1): 25-34.

ROCHA-CAMPOS, A.C.; OLIVEIRA, M.E.C.B. de; SANTOS, P.R. \& SAAD, A.R. 1976. Boulder Pavements and the sense of movement of Late Paleozoic Glaciers in Central Eastern São Paulo State, Brazil. Boletim IG, Inst. Geoc./USP, 7: 149-160.

ROCHA-CAMPOS, A.C.; COTTER, J.F.P. \& SANTOS, P.R. \& CANUTO, J.R. 1992. Boulder Pavement from the Itararé Subgroup (Late Paleozoic) at Capivari,
SP: new evidence on origin. In: CONGRESSO BRASILEIRO DE GEOLOGIA, 37., 1992, São Paulo. Bol. Resumos. São Paulo: SBG, v.1, p. 521522.

SAAD, A.R. 1977. Estratigrafia do Subgrupo Itararé no centro e sul do Estado de São Paulo. São Paulo, Inst. de Geociências/USP, 107p. (Dissertação de mestrado). Inédita.

SOUZA, P.A. de 1996. Palinologia e bioestratigrafia do Subgrupo Itararé em Araçoiaba da Serra (Westphaliano, Bacia do Paraná), Estado de São Paulo, Brasil. São Paulo, Inst. de Geociências/USP, 192 p. (Dissertação de Mestrado). Inédita.

SOUZA FILHO, E.E. 1986. Mapeamento faciológico do Subgrupo Itararé na quadrícula de Campinas, SP. São Paulo, Inst. de Geociências/USP, 121p. (Dissertação de Mestrado). Inédita.

STEVAUX, J.C.; SOUZA FILHO, E.E.; TEIXEIRA, J.A. \& LANDIM, P.M.B. 1987. Sistemas Deposicionais do Subgrupo Itararé (PC) na bacia hidrográfica do baixo rio Capivari (SP): um modelo para a prospecção de água subterrânea. In: SIMPÓSIO REGIONAL DE GEOLOGIA, 6., 1987, Rio Claro. Atas... Rio Claro: SBG, v.1, p. 355-367.

Endereço dos autores:

Setembrino Petri - Instituto de Geociências/USP, Caixa Postal 20.899, CEP 01498-970, São Paulo, SP, Brasil.

Percy Corrêa Vieira; Geraldo Hideo Oda; Pedro Fernandes Botelho - Instituto Geológico/SMA, Av. Miguel Estéfano, 3.900, Caixa Postal 2.972, CEP 04301-903, São Paulo, SP, Brasil. 